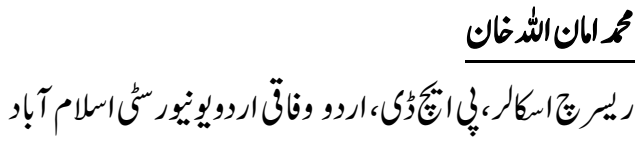

$$
\begin{aligned}
& \text { واكرُمائير }
\end{aligned}
$$

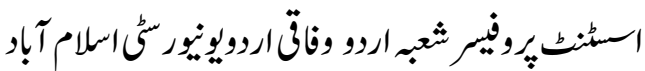

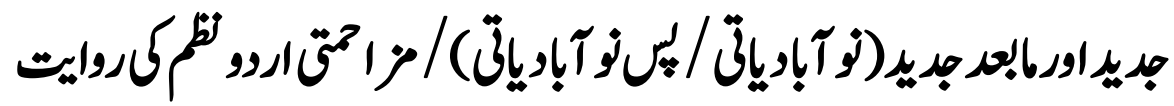

Muhammad Aman Ullah Khan

PhD Urdu Scholar, Department of Urdu, Federal Urdu University Islamabad.

Dr. Naheed Qamar

Assistant Professor, Department of Urdu Federal Urdu University Islamabad.

\title{
Modern and post-modern (colonial / post-colonial) resistance Urdu poetry
}

Colonialism is strictly referred to the policies and Methods by an Imperial Power maintained and extended its control over the territories or People. A policy of extending a Country's Power and influence through diplomacy or military. It also affects the literature of the Subject Country which is controlled by the colonialist. This Article Present an analysis of Colonial system and its impact on Urdu Poem.

Key Words: Revolutionary Struggle, Cultural and Literary identity, Sir Sayyad, Azad, Hali, Post-Colonial, Reaction, Anjuman Punjab.

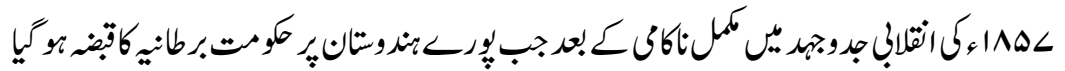

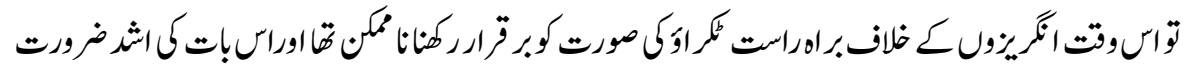

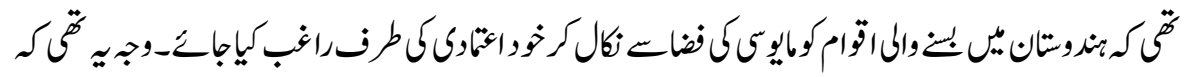

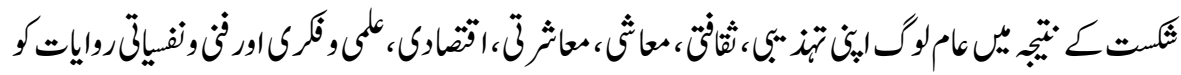

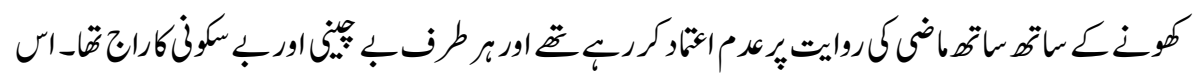




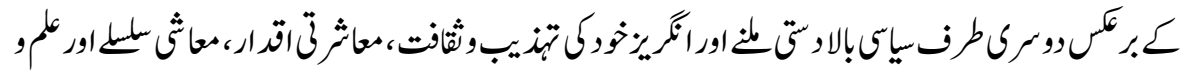

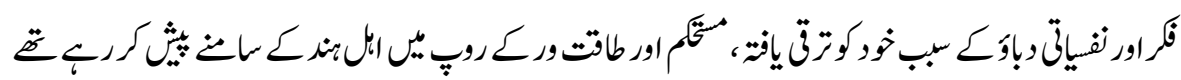

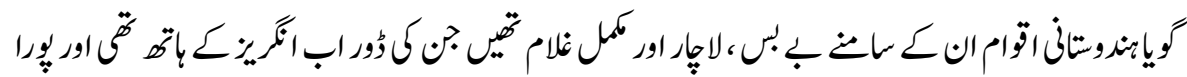

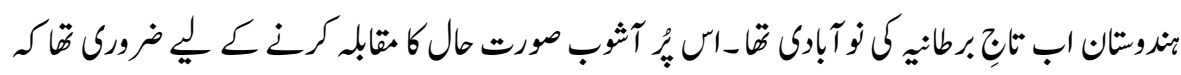

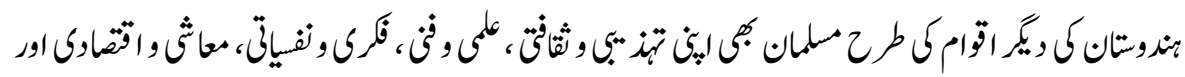

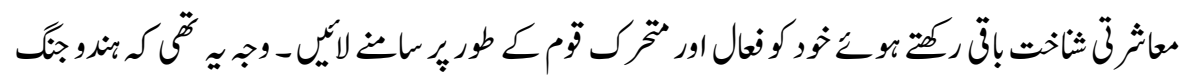

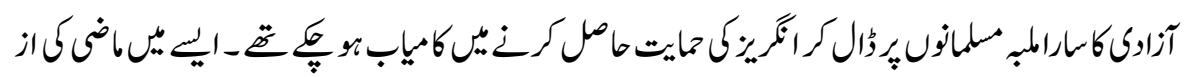

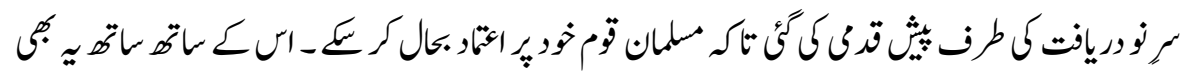

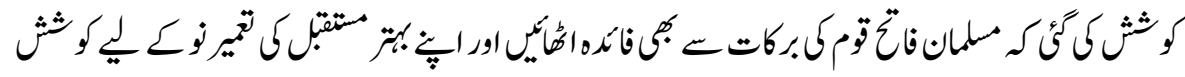

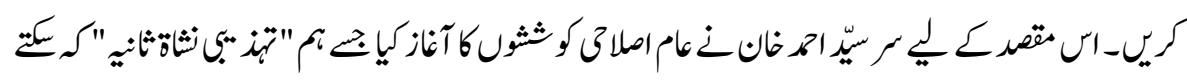

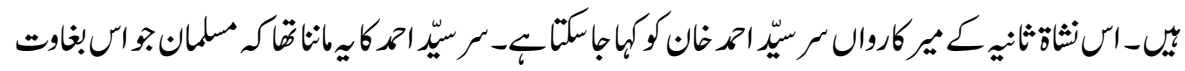

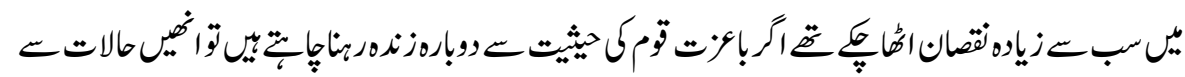

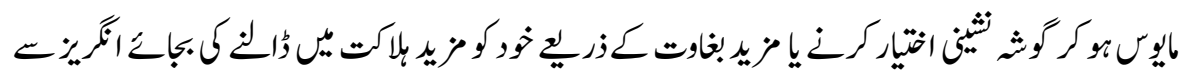

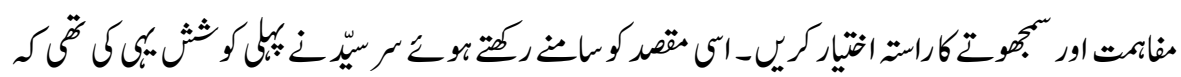

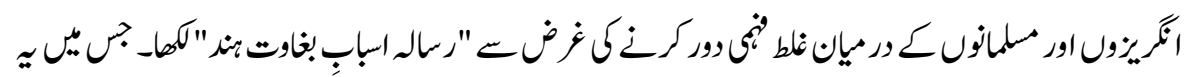

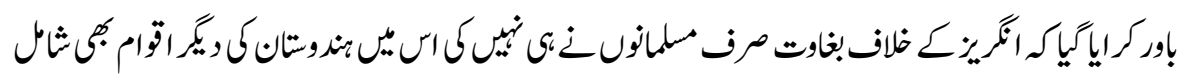

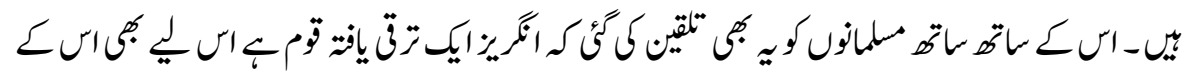

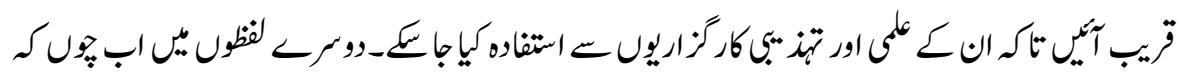

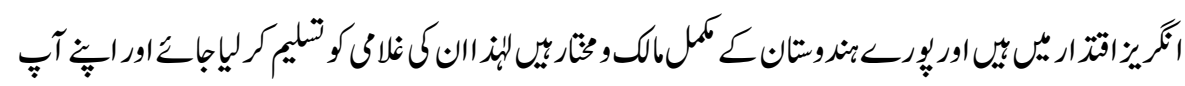

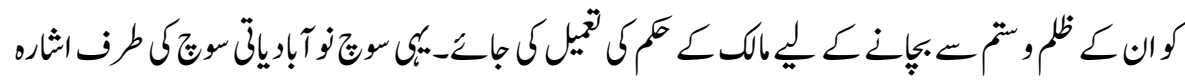

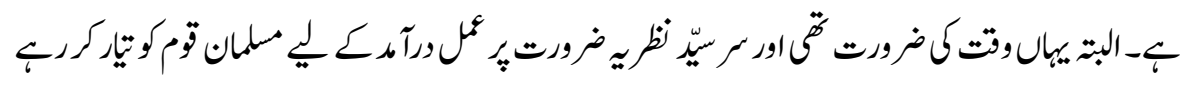




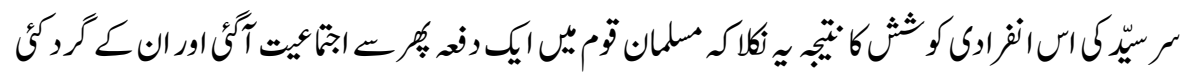

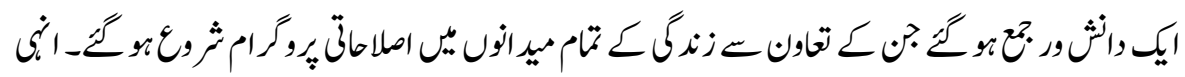

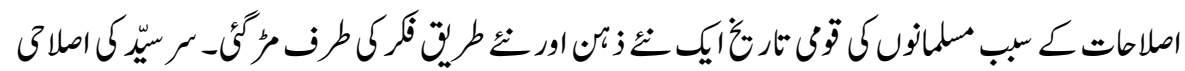

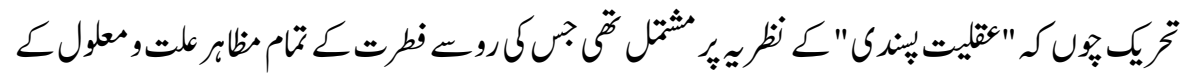

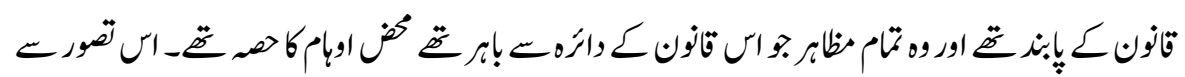

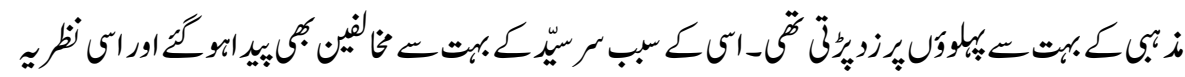

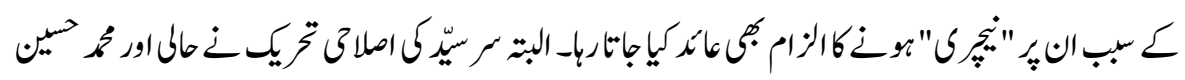

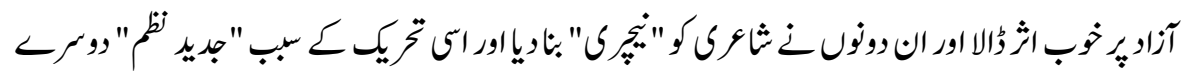

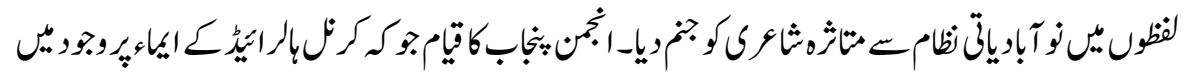

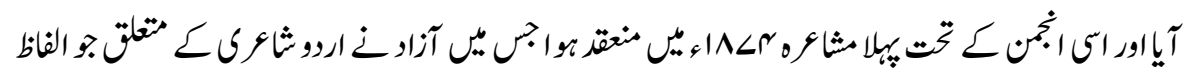

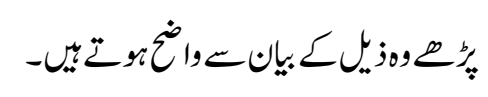

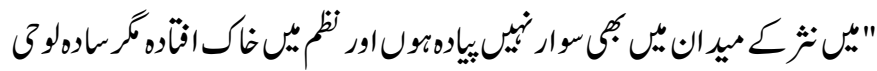

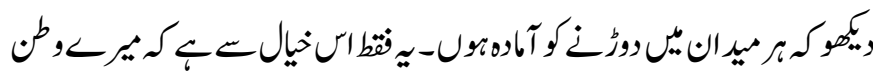

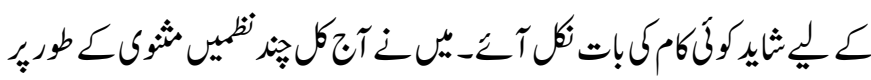

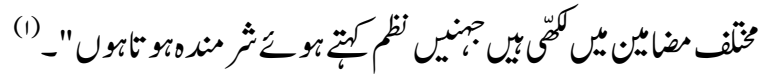

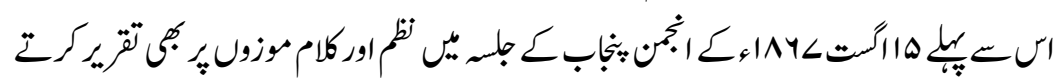

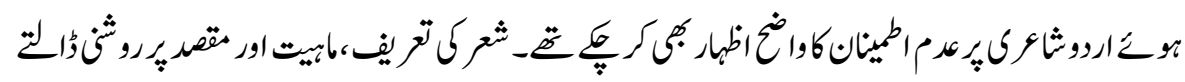

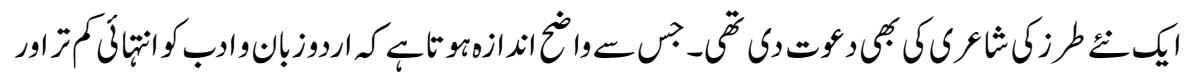

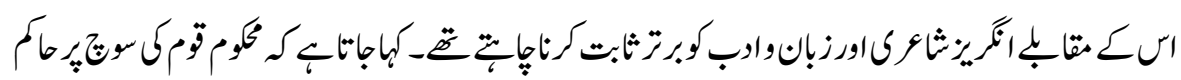

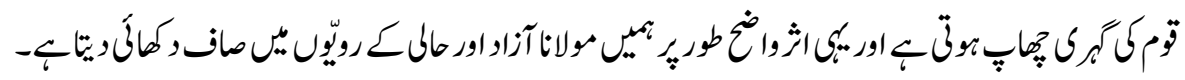

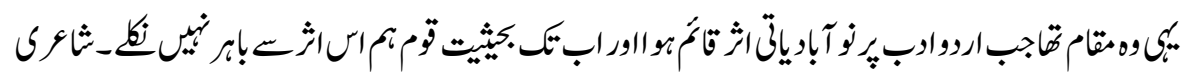

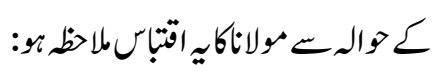




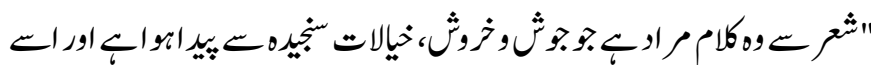

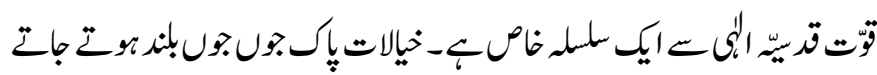
بيل

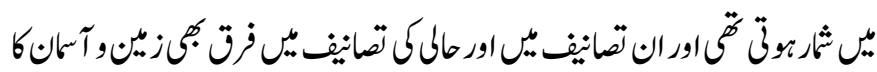

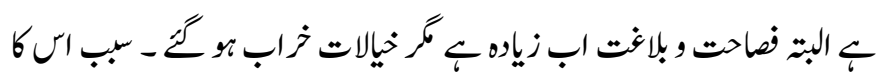

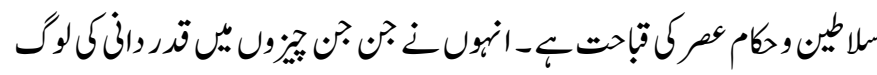

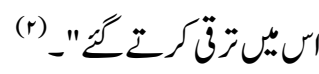

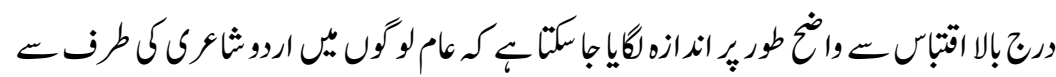

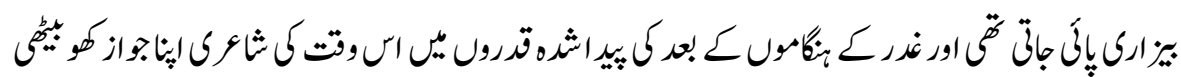

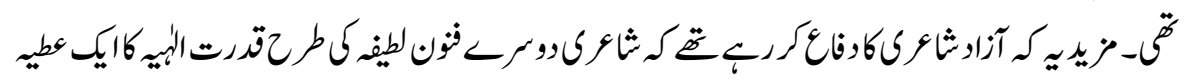

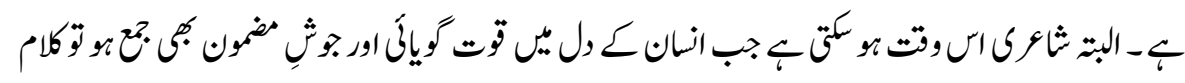

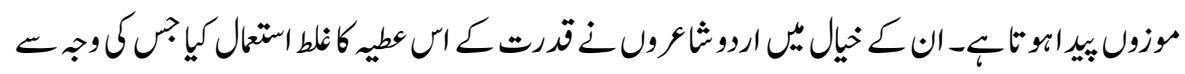

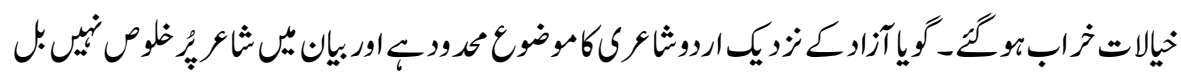

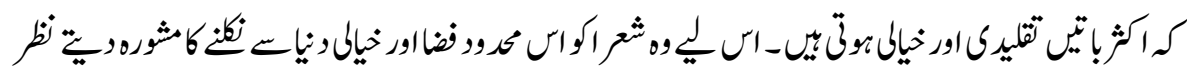

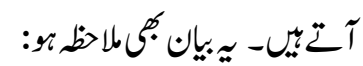

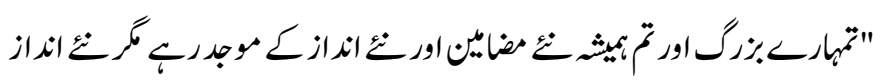

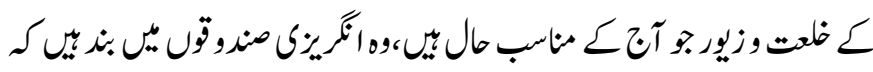

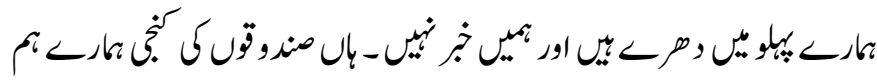

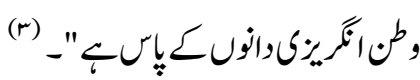

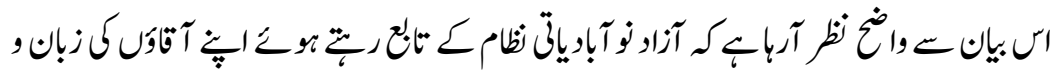

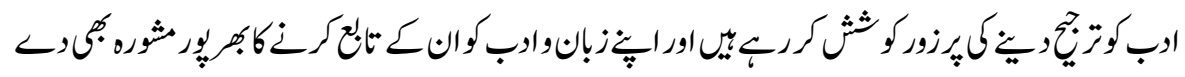

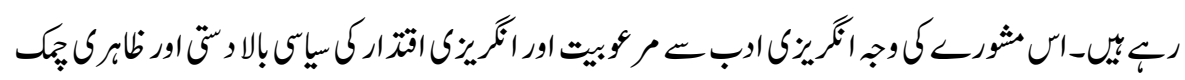

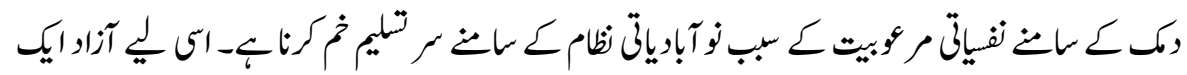




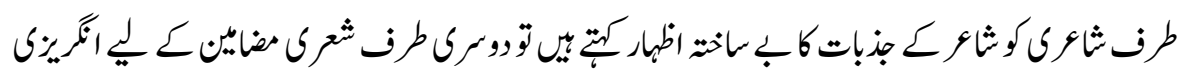

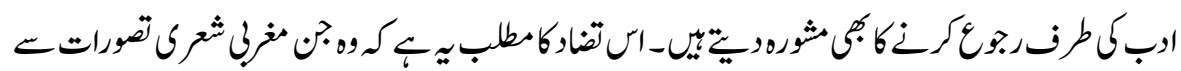

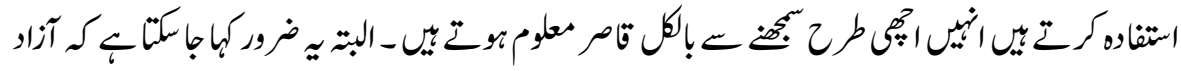

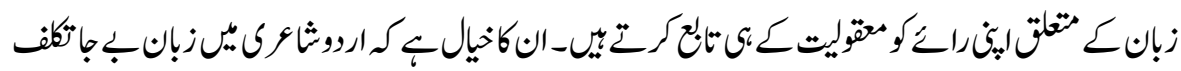

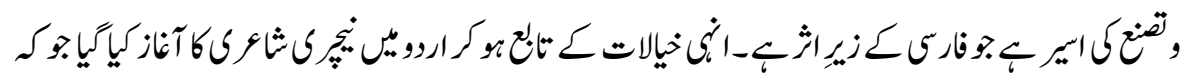

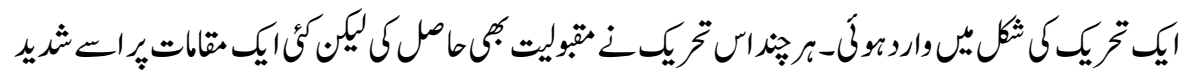

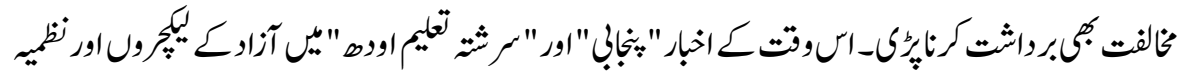

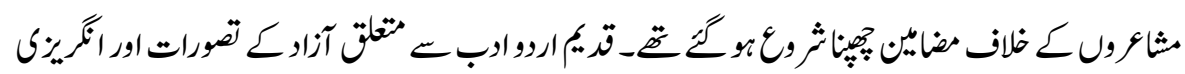

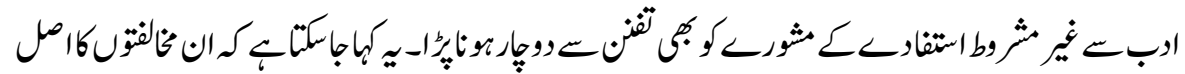

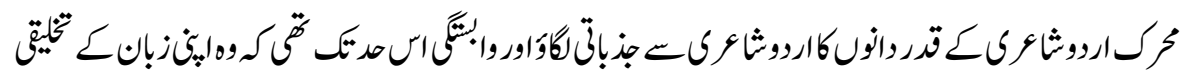

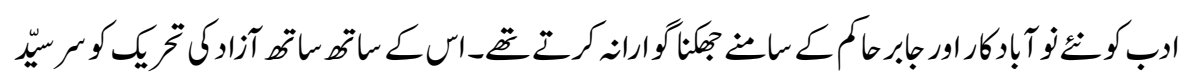

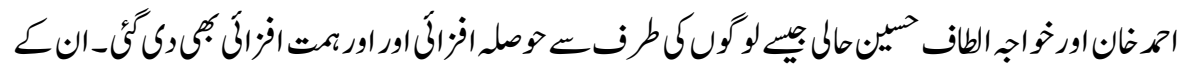

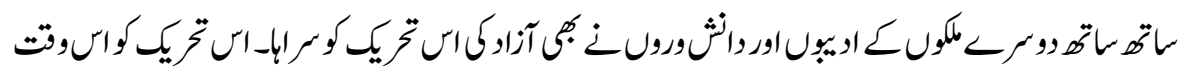

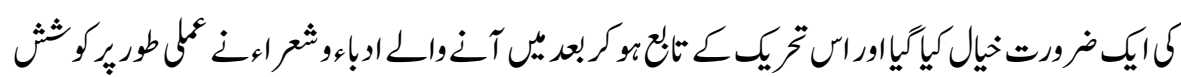

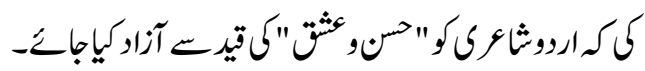

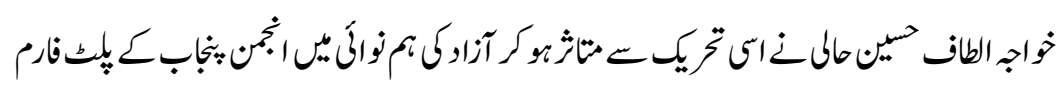

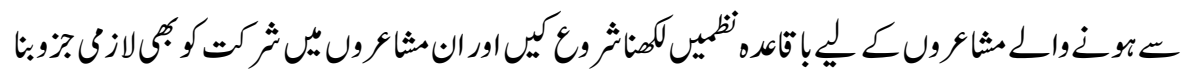

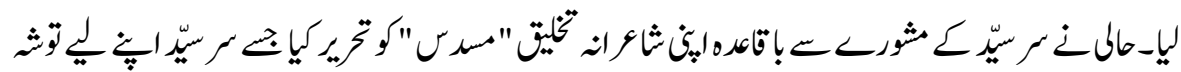

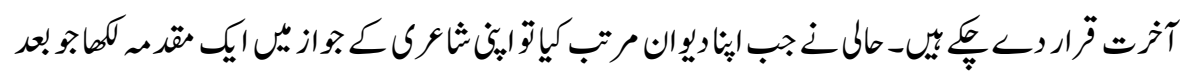

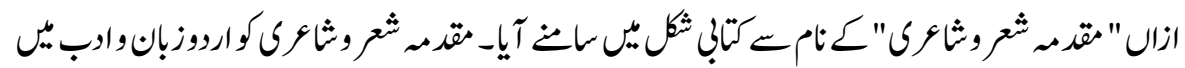

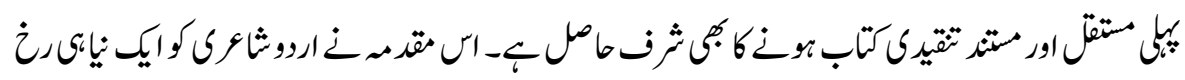

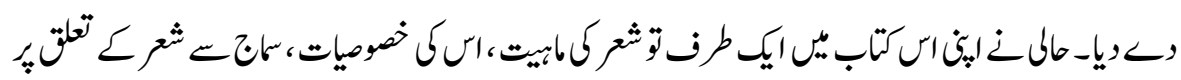

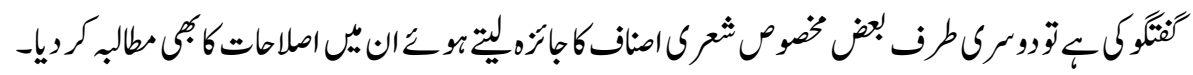




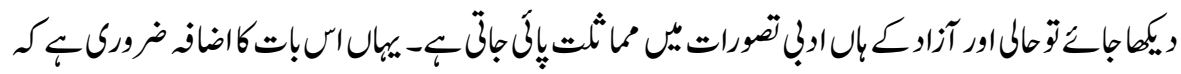

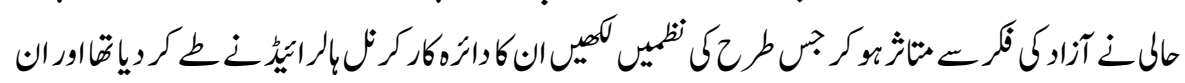

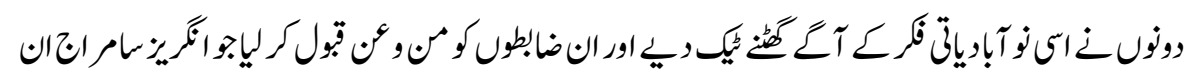

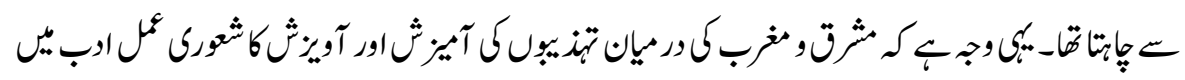

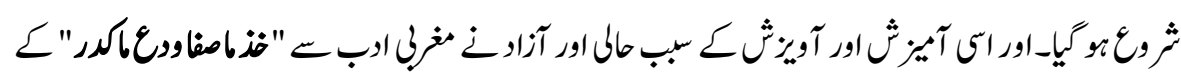

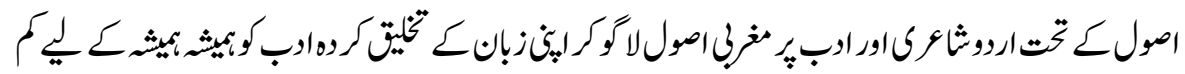

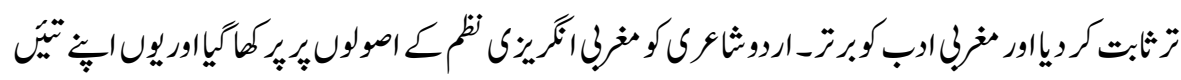

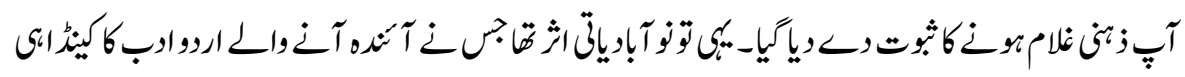

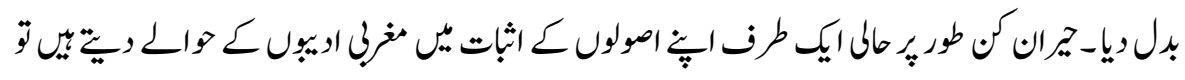

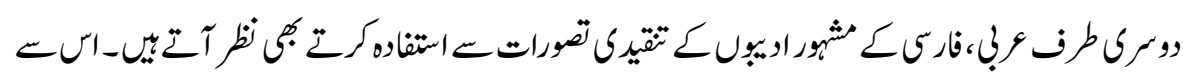

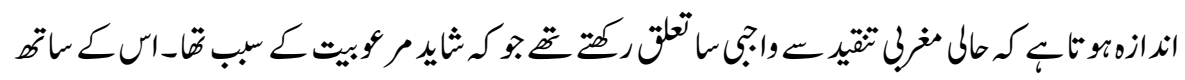

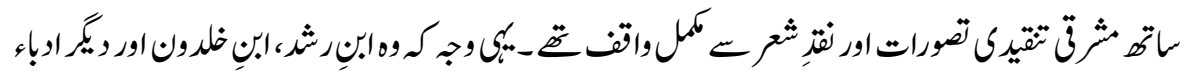

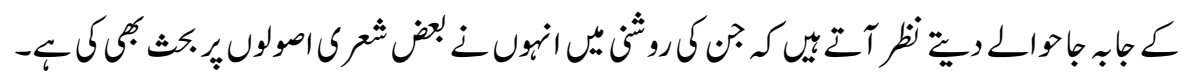

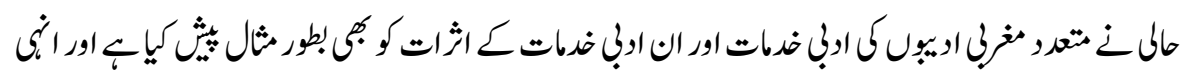

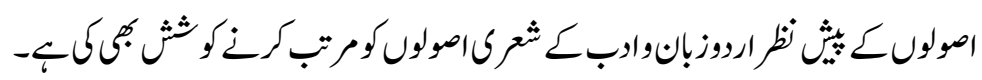

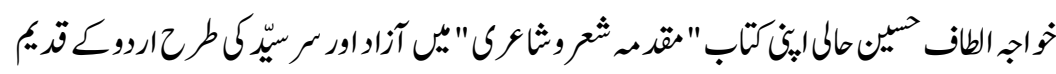

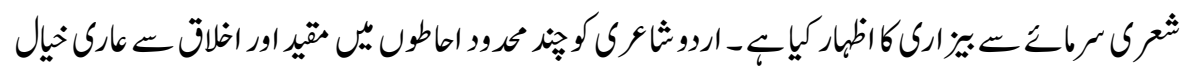

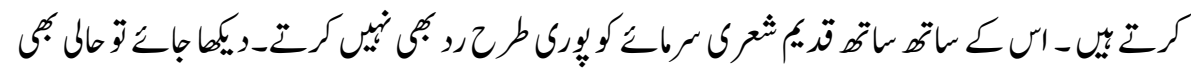

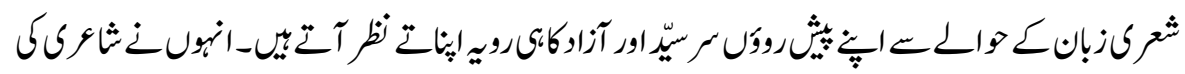

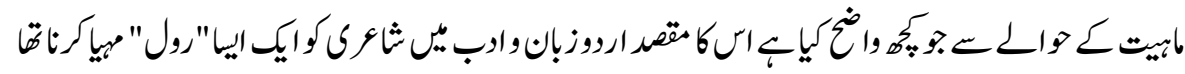

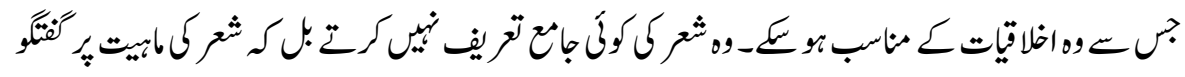
كرتهب 


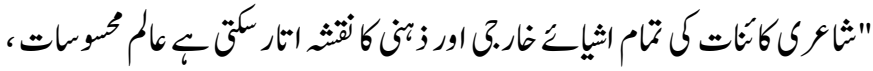

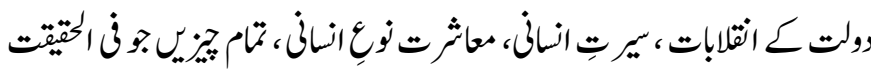

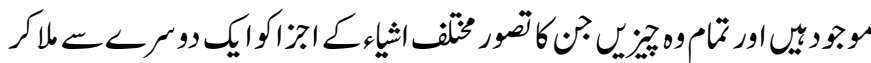

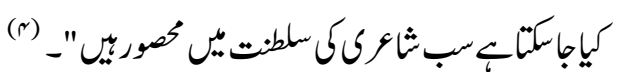

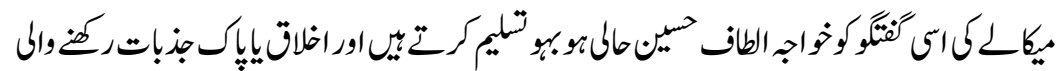

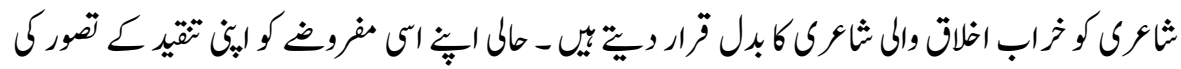

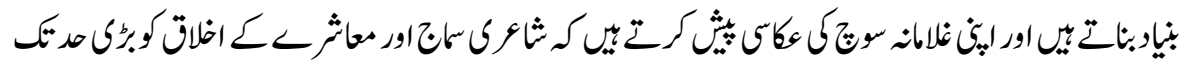

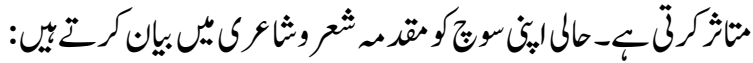

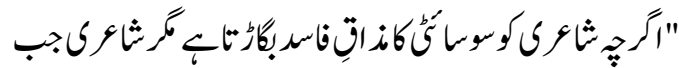

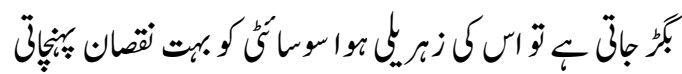

(a) $-"<$

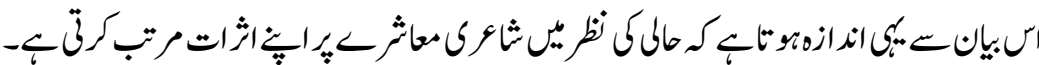

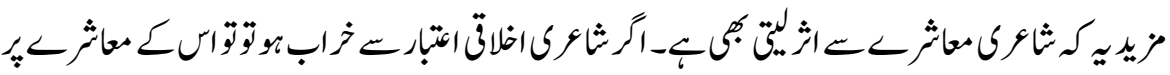

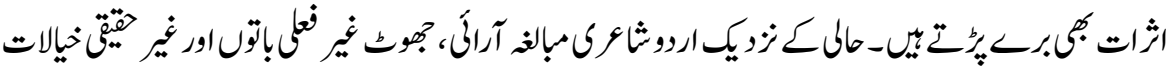

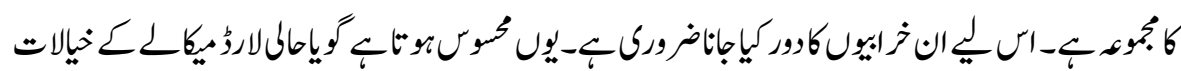

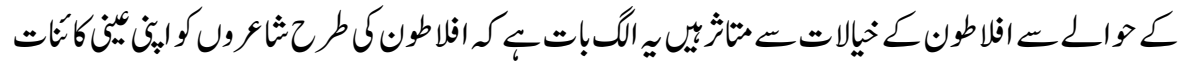

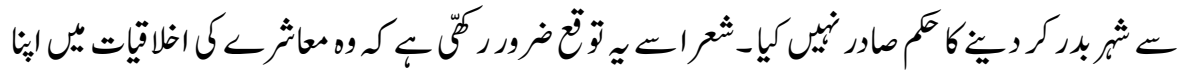

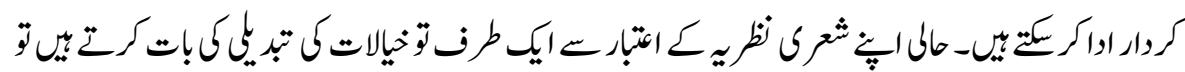

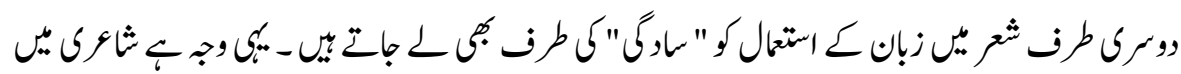

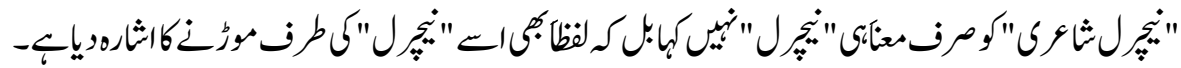
و

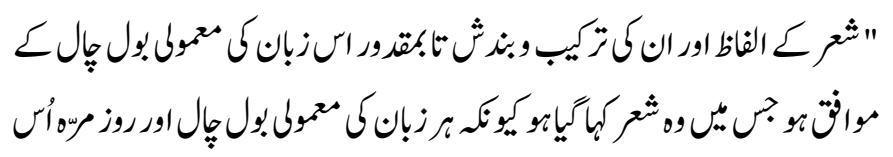




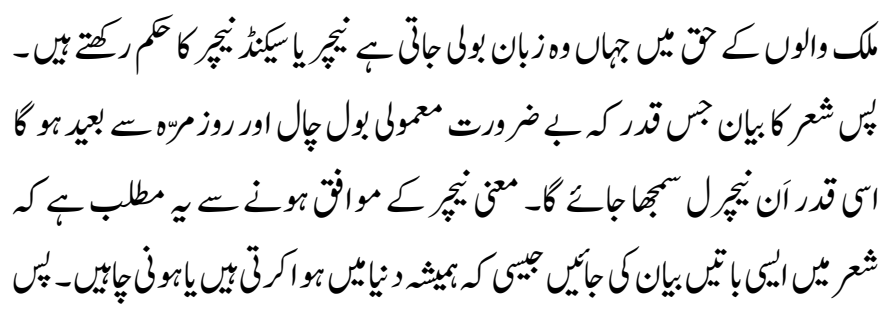

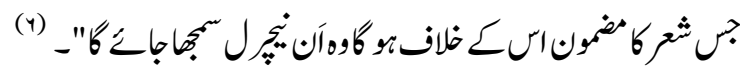

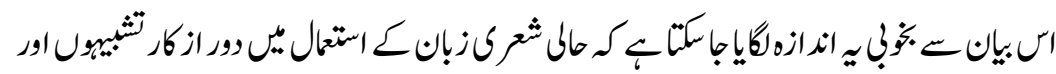

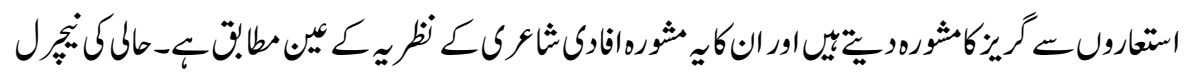

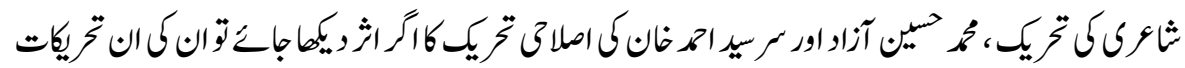

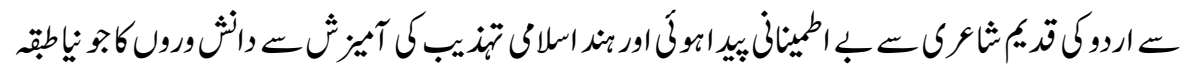

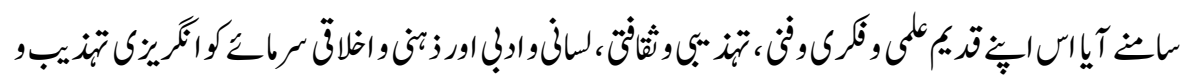

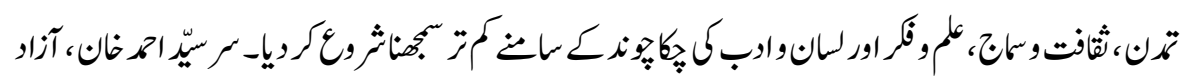

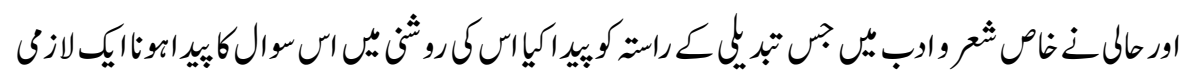

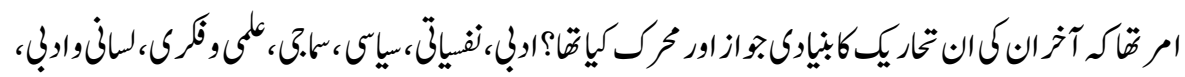

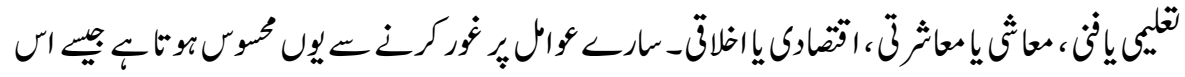

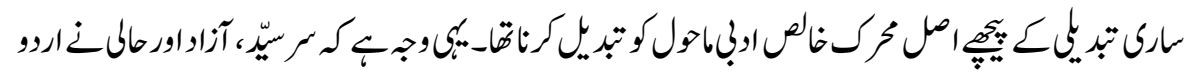

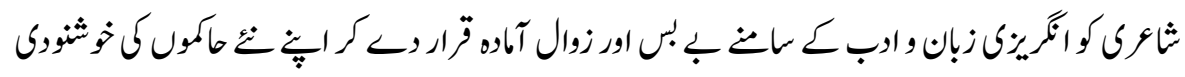

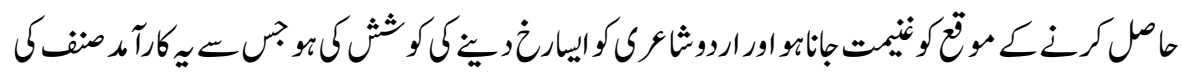

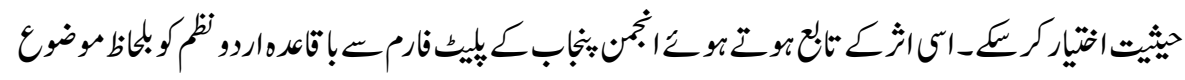

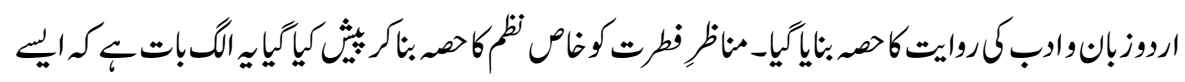

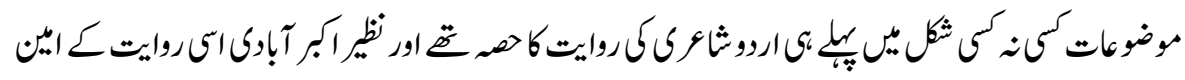

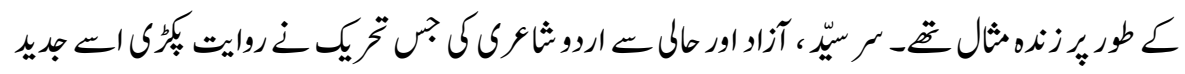

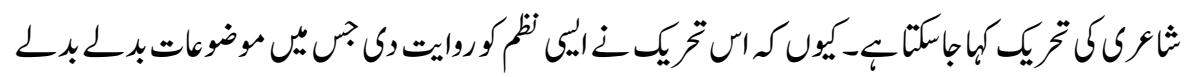




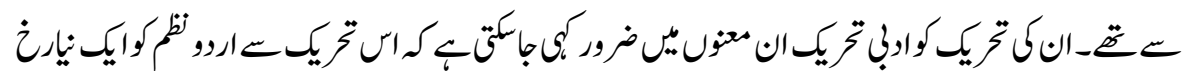

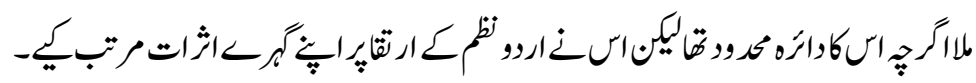

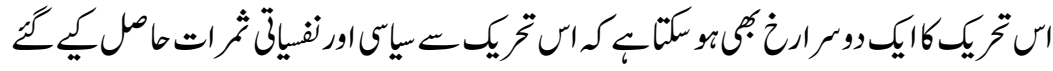

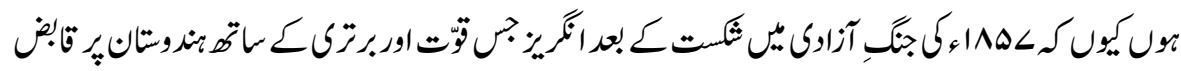

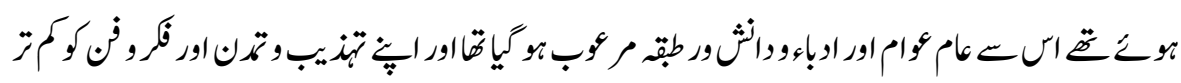

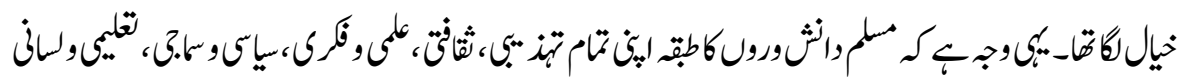

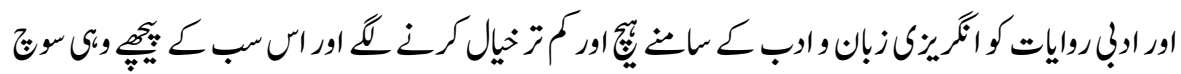

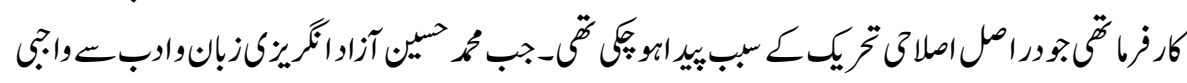

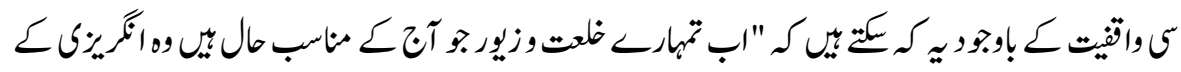

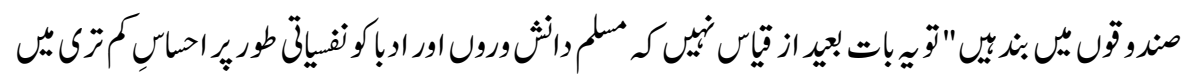

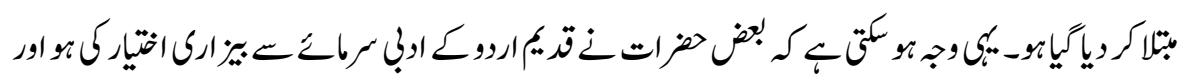

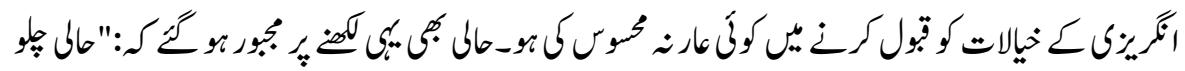

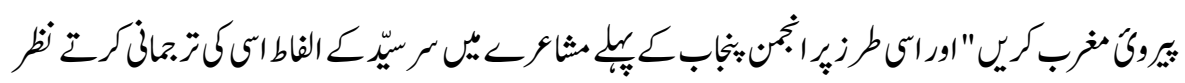

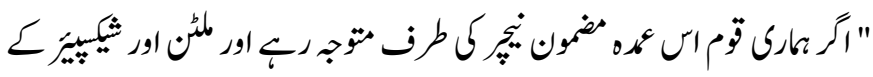

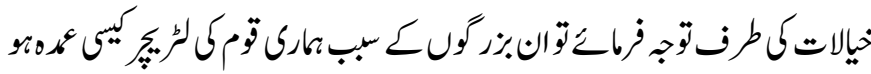

$$
\text { (L) }
$$

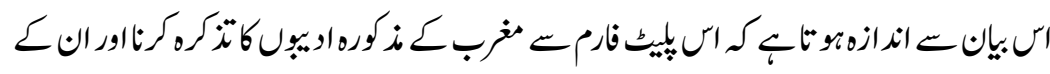

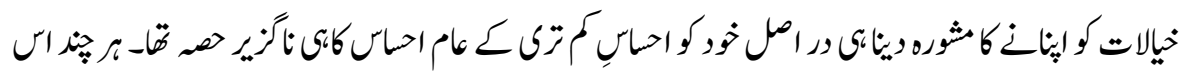

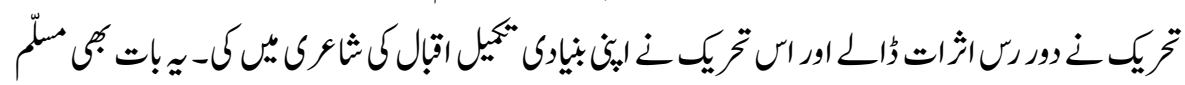

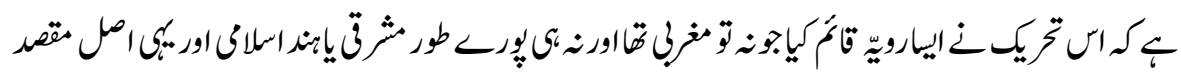

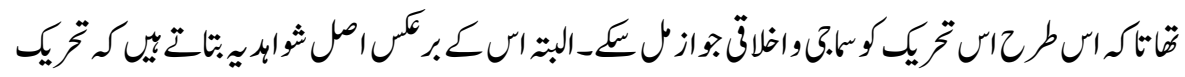




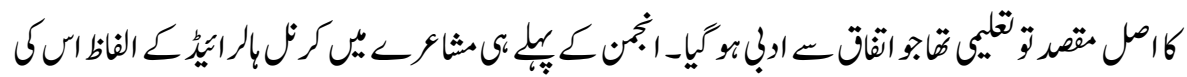
تحمافكرتئ:

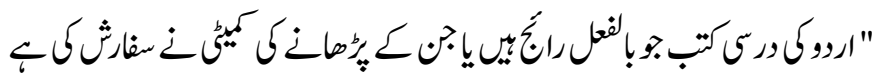

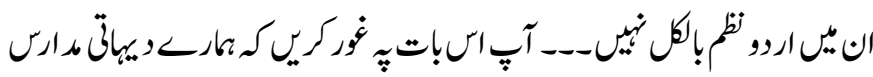

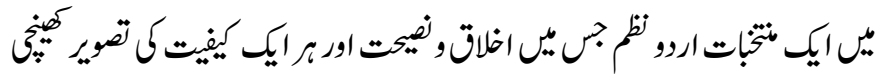

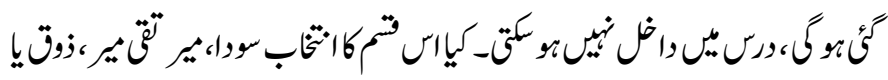

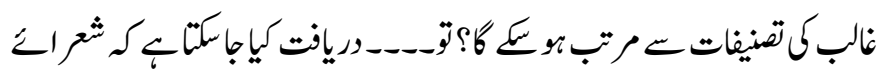

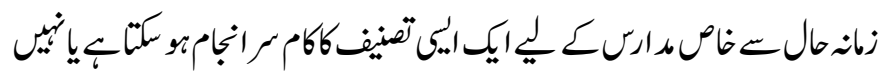

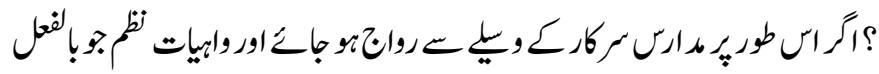

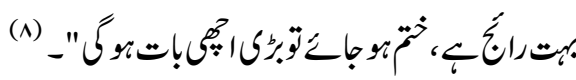

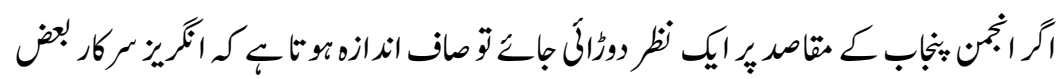

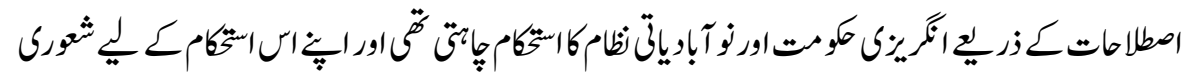

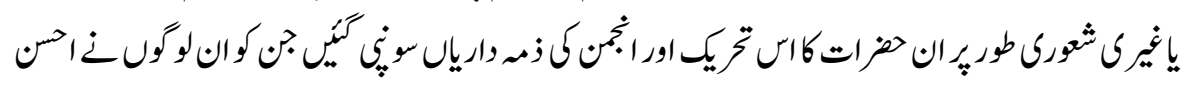

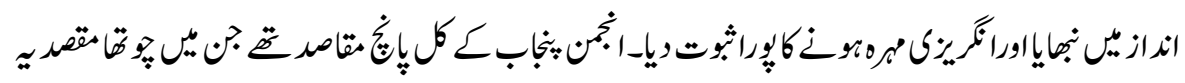
:

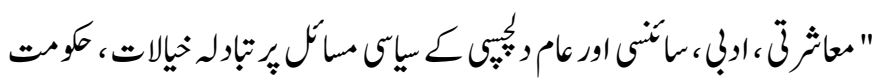

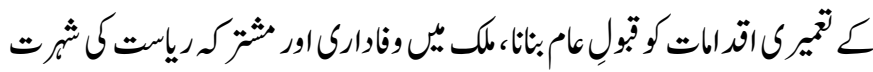

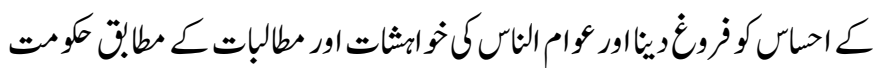

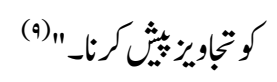

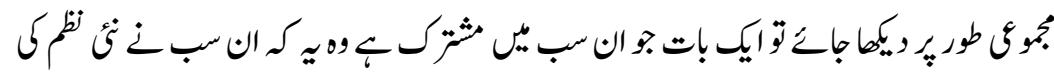

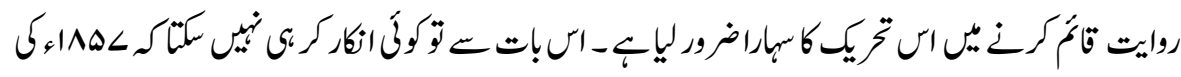

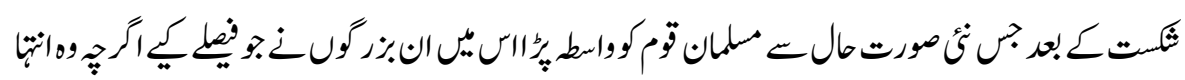

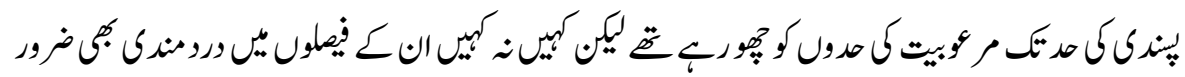




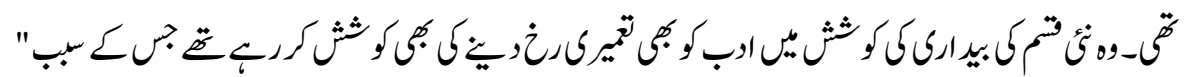

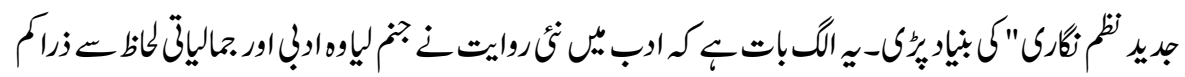

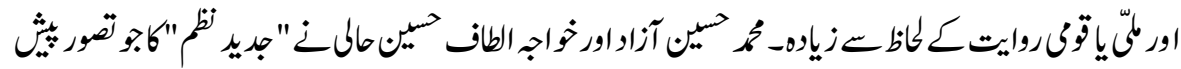

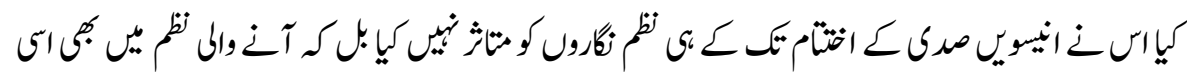

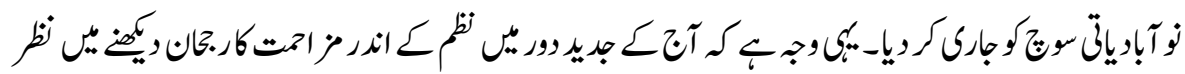

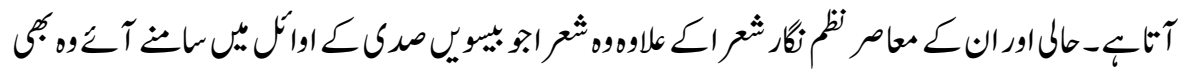

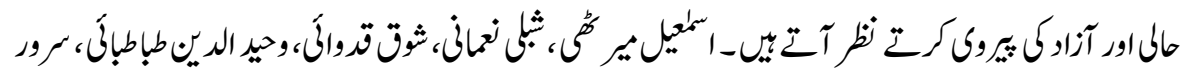

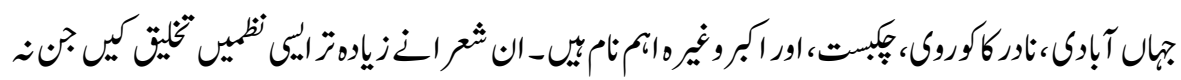

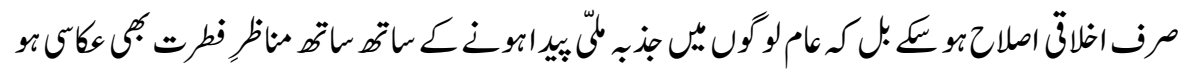

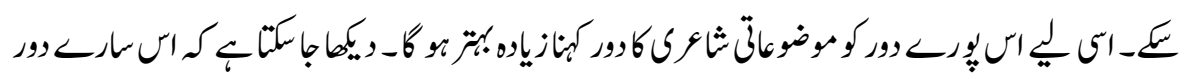

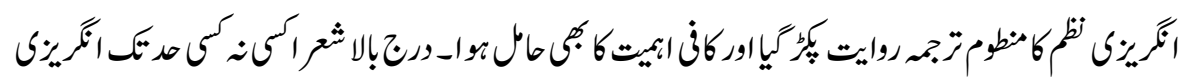

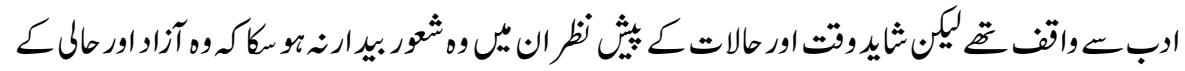

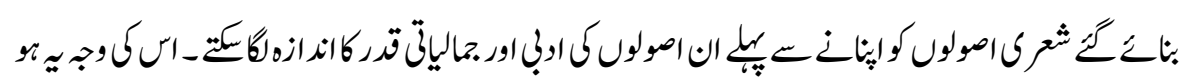

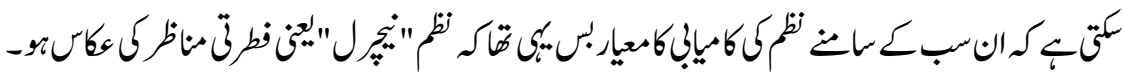

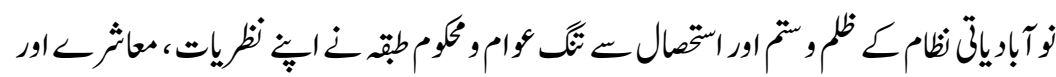

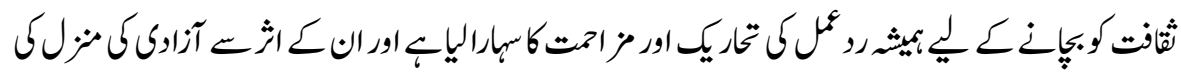

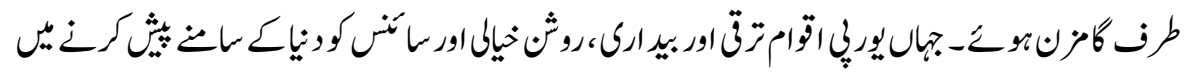

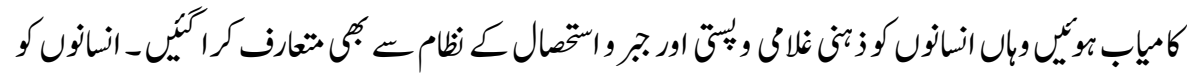

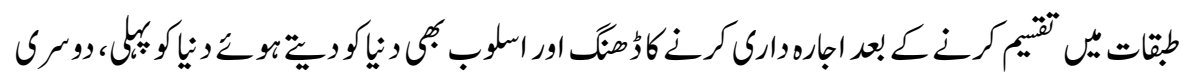

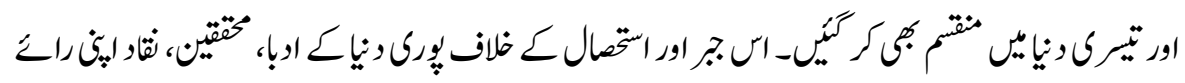

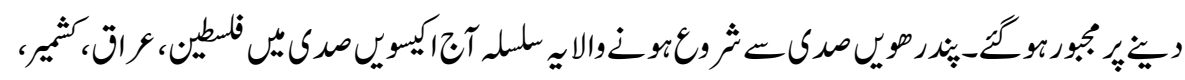

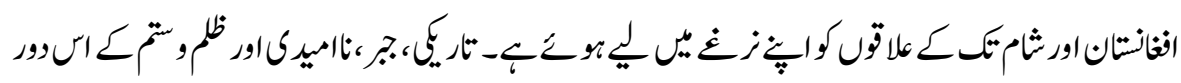

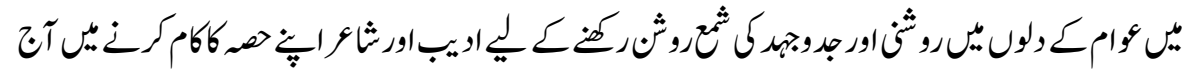




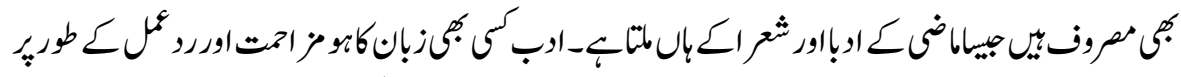

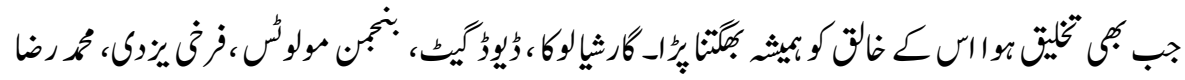

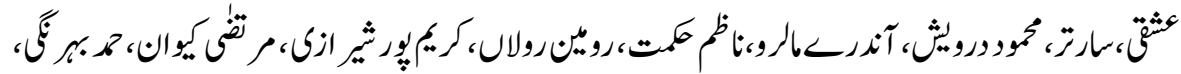

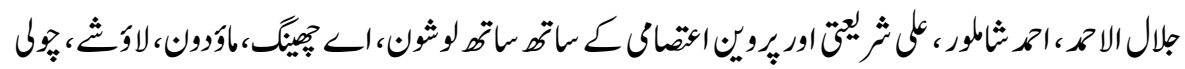

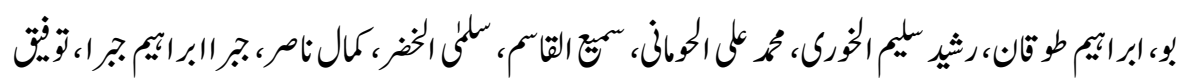

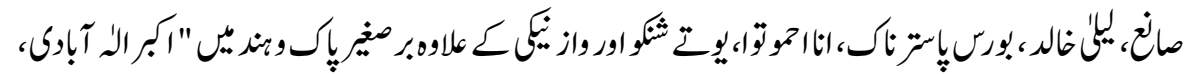

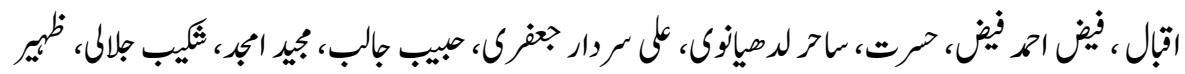

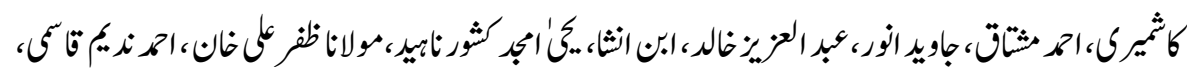

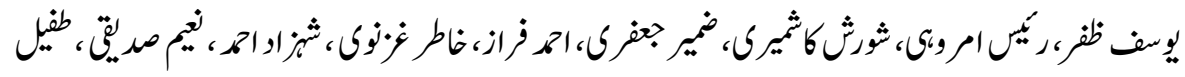

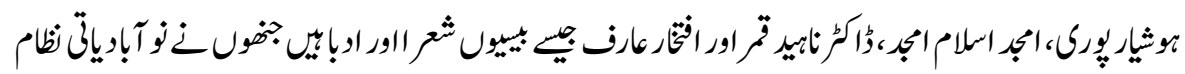

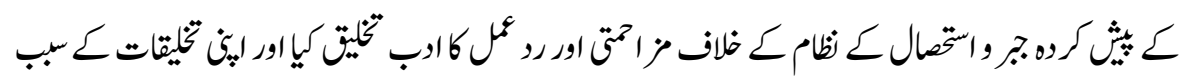

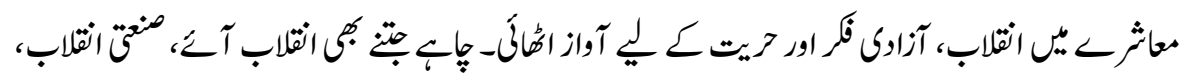

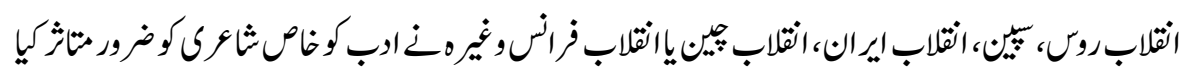

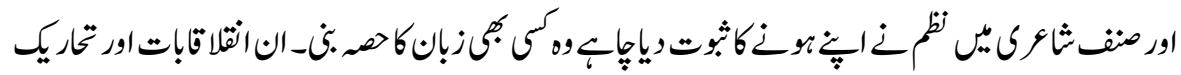

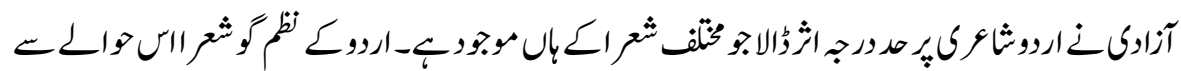

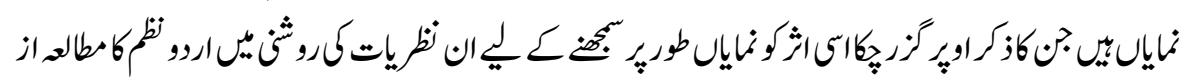

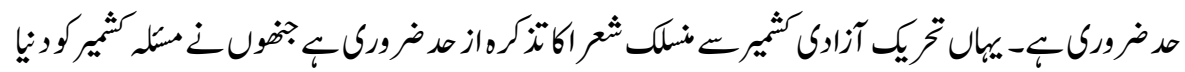

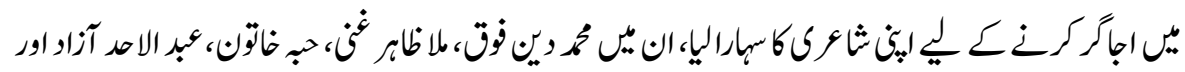

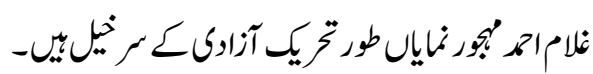

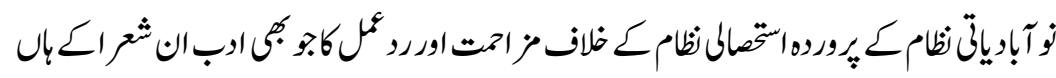

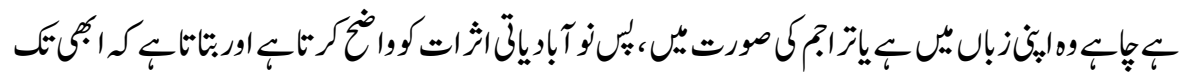

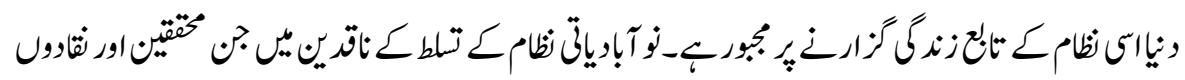

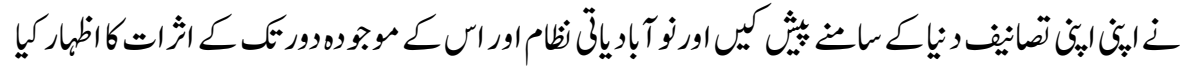




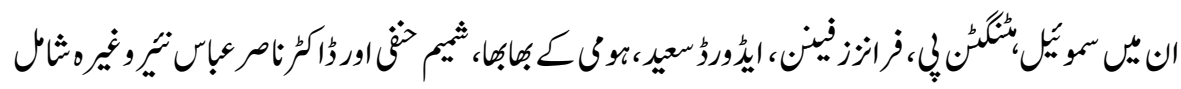

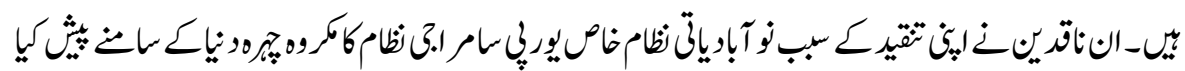

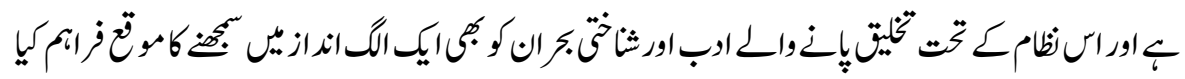

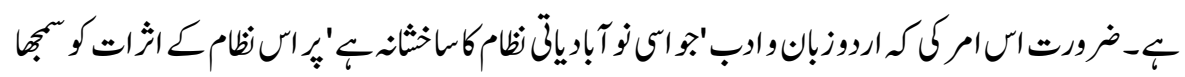

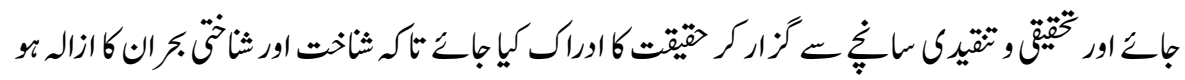

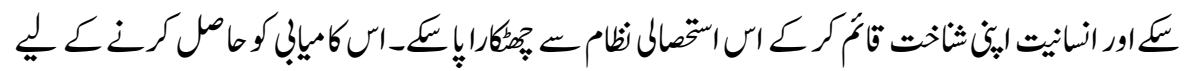

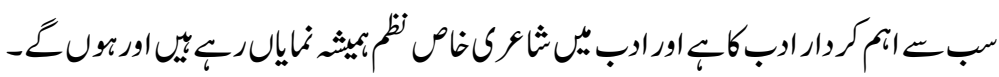

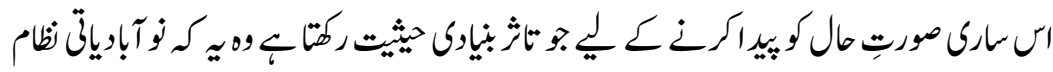

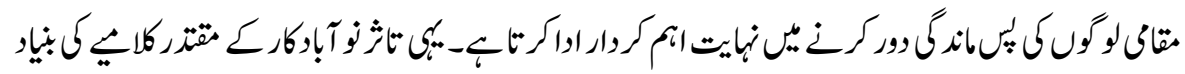

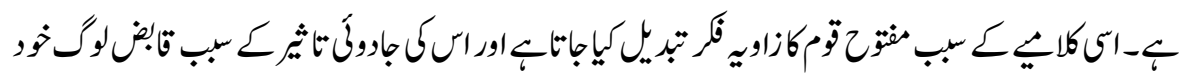

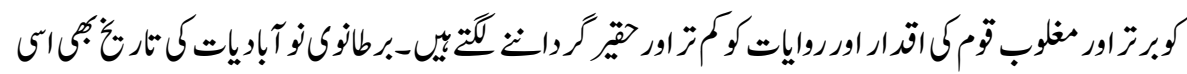

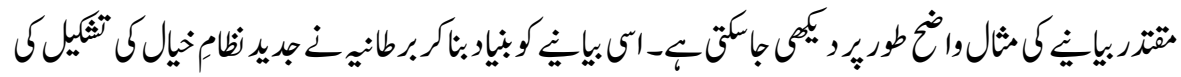

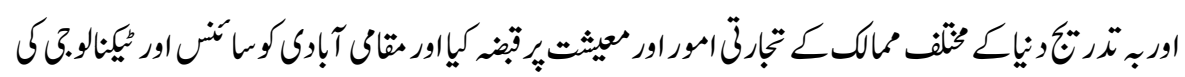

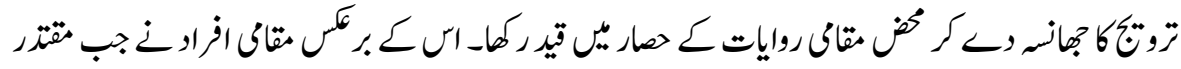

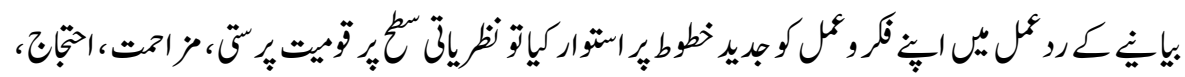

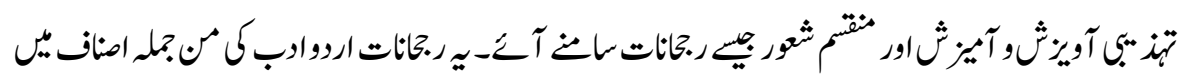

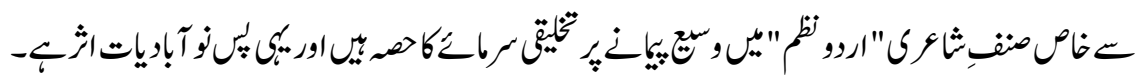

\section{والـجات}

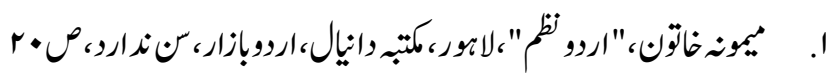

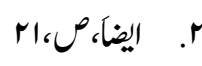

$$
\begin{aligned}
& \text { r. اليضاك، rrr } \\
& \text { r. اليضا، r. }
\end{aligned}
$$




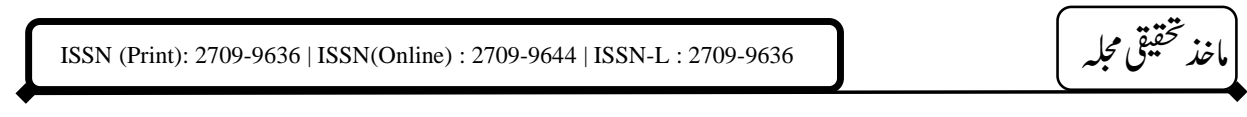

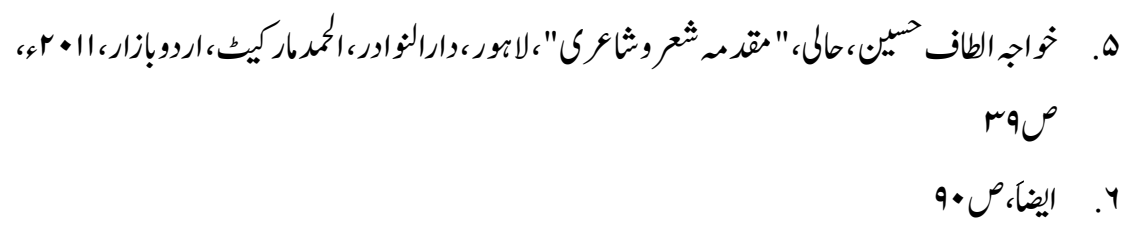

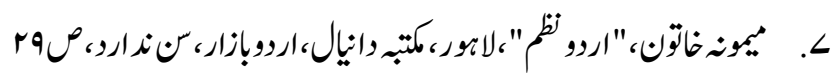

^. اليضاك، •

9. 